DOI: 10.17707/AgricultForest.63.1.14

\author{
Mehmet Salih SAYAR ${ }^{I}$
}

\title{
ADDITIVE MAIN EFFECTS AND MULTIPLICATIVE INTERACTIONS (AMMI) ANALYSIS FOR FRESH FORAGE YIELD IN COMMON VETCH (VICIA SATIVA L.) GENOTYPES
}

\section{SUMMARY}

The study was held to evaluate genotype $\times$ environment interactions and stability status of twenty common vetch (Vicia sativa L.) genotypes in terms of fresh forage yield trait by using additive main effects and multiplicative interactions analysis (AMMI). Field trials of the study were carried out during 2008-09, 2009-10 and 2010-11 growing seasons under the rainfed conditions of two different locations of the Southeastern Anatolia region of Turkey. The field trials were established according to randomized blocks design with three replications. Additive main effects and multiplicative interactions analysis (AMMI) showed that the effect of environments on genotype $\times$ environment interactions were found quite high levels for fresh forage yield trait. The first three principal component axes (IPCA 1 IPCA 2 and IPCA 3) were found highly significant $(P<0.01)$, and they accounted for $93.44 \%$ of the total genotype by environmental interaction. Furthermore, the effect of environments on forage yields of common vetch genotypes was found to be highest (42.23\%), it was followed by genotype $\times$ environment interaction (GEI) (36.13\%) and genotypic effects $(21.64 \%)$. AMMI analysis revealed that with their high yield means, and lower IPCA-1 scores, close to zero, respectively, D-135 (G6), IFVS-2541 (G4) and IFVS-715 (G3) were considered to be possessing high stable fresh forage yields. Therefore, these genotypes should be preferred for forage yield production in Southeastern Anatolia region conditions.

Keywords: AMMI analysis, fresh forage yield, common vetch, genotype $\times$ environment interactions, stability

\section{INTRODUCTION}

Common vetch (Vicia sativa L.) is one of the most highly cultivated annual legume forage species in Turkey and worldwide. It is typically grown for its forage and seeds and is also used as green manure (Cakmakci et al., 2003). As a legume species, common vetch contributes to increased nitrogen content in the soil and prevents disease in subsequent crops in crop rotation systems (Ayed et al., 2001; Caballero et al., 2001). Common vetch forage is nutritious due to its

\footnotetext{
${ }^{1}$ Mehmet Salih Sayar (corresponding author: msalihsayar@hotmail.com) Department of Crops and Animal Production, Bismil Vocational Training High School, Dicle University, 21500, Bismil, Diyarbakır, TURKEY

Paper presented at the $7^{\text {th }}$ International Scientific Agricultural Symposium "AGROSYM 2016".

Notes: The authors declare that they have no conflicts of interest. Authorship Form signed online.
} 
high protein content and it is eagerly consumed by livestock due to its taste, without an accompanying risk of swelling (Acikgoz, 2001). A shortage of quality roughage is a serious problem for animal husbandry in Turkey, particularly in the Southeastern Anatolia Region (Sayar et al., 2010). Plant breeders attempt to alleviate this deficiency by improving and introducing higher yield forage cultivars (Sayar et al. 2013).

Yield is a complex trait that depends on many other traits and is greatly affected by environmental factors. However; plant breeders and farmers demand stable varieties, has high mean yield but showing little fluctuation in performance when grown over various environments. Therefore; genotype-environment interactions (GEI), response of genotypes to different environments, are extremely important in plant breeding programs when introducing new crop cultivars (Sayar et al., 2013; Kendal and Dogan, 2015).

The additive main effects and multiplicative interaction (AMMI) analysis is one of the most useful and the most commonly used method in determining and evaluation of the GEI. AMMI model is a hybrid model combines the analysis of variance (ANOVA) and the principal component analysis (PCA) in a single model (Gauch and Zobel, 1996; Mirosavljević et al., 2014; Islam et al., 2014). Among the reasons for the preference of AMMI analysis by researchers are that firstly, this method is quite effective revealing GEI, secondly, it can show impact degree of genotypes, environments and GEI on performance of genotypes separately, (Ebdon and Gauch, 2002; Tarakanovas and Ruzgas, 2006; Asfaw et al., 2009), finally, the results of AMMI analysis shown in common graphs are called biplot (Gabriel, 1971) and these AMMI biplot graphs enable us to find out explicitly which genotypes suitable for which environment and stability status of genotypes. Accordingly, the objectives of the study were to (i) explicate GEI obtained by AMMI analysis of yield performances of twenty common vetch genotypes over five environments, (ii) visually evaluate variation of yield performances across environments based on the AMMI biplot and (iii) determine genotypes with high fresh forage yield stability.

\section{MATERIALS AND METHODS}

Plant genetic materials: The study materials consisted of 20 common vetch (Vicia sativa L.) genotypes, seven cultivars, and thirteen promising lines. The used cultivars were Alinoglu-2001, Dicle, Gorkem, Kralkizi, Kubilay-82, Ozveren and Uludag. On the other hand, among the used five promising lines, IFVS-715, IFVS 2427, IFVS 2541, IFVS 3091 and IFVS 3889 were supplied from International Center for Agricultural Research in Dry Areas, Aleppo, Syria (ICARDA). In addition, the three promising lines, D-71, D-72 and D-135 belonged to GAP International Agricultural Research and Training Centre (GAP IARTC). Only Line-22 was supplied from Cukurova University Agriculture Faculty Field Crops, Adana, Turkey. The remaining four promising lines, GAP2604, GAP 2490, GAP 61721, GAP 59998, were obtained from the Eastern Mediterranean Agricultural Research Institute, Adana, Turkey. 
Table 1. Climatic and soil information of the environments where the genotypes tested

\begin{tabular}{|c|c|c|c|c|c|c|c|}
\hline $\begin{array}{c}\text { Environ } \\
\text { ments }\end{array}$ & $\begin{array}{c}\text { Growing } \\
\text { seasons }\end{array}$ & $\begin{array}{c}\text { Locat } \\
\text { ions }\end{array}$ & $\begin{array}{c}\text { Alti } \\
\text { tude } \\
(\mathbf{m})\end{array}$ & $\begin{array}{c}\text { Soil } \\
\text { properties }\end{array}$ & $\begin{array}{c}\text { Sowing } \\
\text { date }\end{array}$ & $\begin{array}{c}\text { The } \\
\text { average } \\
\text { tempera } \\
\left.\text { ture } \mathbf{(}^{\circ} \mathbf{C}\right)\end{array}$ & $\begin{array}{c}\text { Total } \\
\text { rain } \\
\text { fall } \\
(\mathbf{m m})\end{array}$ \\
\hline $\mathrm{E} 1$ & $\begin{array}{c}2008- \\
2009\end{array}$ & Diyarbakır & 603 & $\begin{array}{c}\mathrm{pH}=7.86 \\
\text { clay-loam }\end{array}$ & 14.11 .2008 & 12.40 & 455.0 \\
\hline $\mathrm{E} 2$ & $\begin{array}{c}2009- \\
2010\end{array}$ & Diyarbakır & 607 & $\begin{array}{c}\mathrm{pH}=7.86 \\
\text { clay-loam }\end{array}$ & 20.11 .2009 & 14.30 & 517.9 \\
\hline E3 & $\begin{array}{c}2010- \\
2011\end{array}$ & Diyarbakır & 605 & $\begin{array}{c}\mathrm{pH}=7.86 \\
\text { clay-loam }\end{array}$ & 11.11 .2010 & 13.60 & 553.0 \\
\hline E4 & $\begin{array}{c}2008- \\
2009\end{array}$ & Hazro & 815 & $\begin{array}{c}\mathrm{pH}=7.65 \\
\text { clay-loam }\end{array}$ & 06.11 .2008 & 11.90 & 927.4 \\
\hline E5 & $\begin{array}{c}2009- \\
2010\end{array}$ & Hazro & 808 & $\begin{array}{c}\mathrm{pH}=7.64 \\
\text { clay-loam }\end{array}$ & 17.11 .2009 & 13.80 & 1055.6 \\
\hline
\end{tabular}

Soil and climatic properties: Soil, climatic and other data of environments where the experiments were conducted are given in Table 1 . The environments soils $(0-30 \mathrm{~cm})$ had a clay loam texture, with a slightly alkaline $\mathrm{pH}$. The soils were rich in calcium and potassium content, but they were poor in organic matter $(0.5-3 \%)$ and useful phosphorus. The Southeastern Anatolia region is one of Turkey's seven census-defined geographical regions, and the region is characterized by a continental climate. In this region, summers are dry and hot, whereas winters are cool and rainy.

\section{Field experiments}

The field trials in Diyarbakır location were carried out in the experimental fields of the GAP International Agricultural Research and Training Centre (GAP IARTC) in Diyarbakir, Turkey, and in Sarıcanak village, Hazro district were carried out in the farmer's fields. All of the experiments were conducted under rainfed conditions according to a randomized complete block design with three replications. Each plot consisted of 6 rows with $5 \mathrm{~m}$ in length, and rows were spaced $20 \mathrm{~cm}$ apart. Diammonium phosphate fertilizer (DAP 18-46-00) $(150 \mathrm{~kg}$ $\mathrm{ha}^{-1}$ ) was applied in the experimental plots with the sowings. Weeds appearing in the experimental area were controlled by hand. The seeding rate was 200 seeds $\mathrm{m}^{-2}$ (Acikgoz, 2001). The sowings were made by using an experimental drill. At harvest a half-meter at the beginning and end of each plot was neglected to account for edge effects. For determining fresh forage yield genotypes; each plot was harvested separately in full flowering time. Then, the fresh forage yield was weighed immediately without weight losing. And, the determined fresh forage yield value was converted to hectare for each plot.

\section{Statistical analysis}

ANOVA and Genotype-Environment Interaction (GEI) were estimated by the AMMI model (Zobel et al., 1988). All data were subjected to analysis using GenStat 14.1. software package (VSN International, 2011). 


\section{RESULTS AND DISCUSSION}

The AMMI analysis of variance of fresh forage yield $\left(\mathrm{t} \mathrm{ha}^{-1}\right)$ of the 20 common vetch genotypes tested in five environments showed that the environments $(\mathrm{E})$, genotypes $(\mathrm{G})$, genotype $\times$ environment interactions (GEI) were found statistically highly significant ( $p<0.01$ ). In addition, $42.23 \%$ of the total sum of squares (SS) was attributable to environmental effects, and $21.64 \%$ to genotypic effects $(\mathrm{G})$, and $36.13 \%$ to GEI effects (Table 2). Similarly, many researchers reported that environmental effects were greater than genotypic effects on yield characters of genotypes (Kaya et al.,2002; Ilker et al., 2011; Sayar et al., 2013; Kiliç, 2014; Georgieva and Kosev, 2016; Kendal, 2016). A large sum of squares for environments indicated that the environments were significantly different each other, and the differences among environmental means causing most of the variation in fresh forage yield. The magnitude of the GEI sum of squares was 1.6 times larger than that for genotypes, indicating that there were a great variation in rankings of fresh forage yields of the common vetch genotypes with changing the environmental changes. AMMI analysis of the forage yield of genotypes were revealed that the mean squares of the first three IPCAs (Interaction Principal Component Axes) were significant at $P<0.01$ level. And IPCA 1, IPCA 2 and IPCA 3 cumulatively contributed to $91.46 \%$ of the total GEI (Table 2). Hence, the model was adequate enough to explain the total genotype $\mathrm{x}$ environment interaction component.

In the AMMI-1 biplot, $x$ axis represents the genotypes and environment main effect. If an environment has higher yield than grand mean represents favourable environmental condition. And it locates in right side of the $\mathrm{x}$ coordinate. Accordingly, in the study; E1 and E4 environments had higher forage yield than grand forage mean, for they represented favourable environmental conditions. In contrast, forage yield of E2, E3 and E5 environments were to be lower than grand mean, and these three environments represented unfavourable environmental conditions. In the same way, if its yield is lower than grand mean, it locates in left side of the $\mathrm{x}$-coordinate, and it represents unfavourable environmental conditions. Similarly, if a genotype locates on the right side of $x$ axis, it represents adaptability to favourable environmental conditions. If a genotype locates on the left side of $\mathrm{x}$ axis, it represents adaptability to unfavourable environmental conditions. In the study, exclusively G4, G6, G13, G17, G18 had much higher fresh forage yield than grand mean, and they showed adaptability to favourable environmental conditions. However, G7, G8, G16, G19 had less forage yield than grand mean, for they showed adaptability to unfavourable environmental conditions. On the other hand, G1, G2, G3, G5, G9, G15 gave almost as much as grand mean forage yield, and they generally located in middle of $\mathrm{x}$ - axis, close to grand mean line, in the AMMI-1 biplots. Therefore they showed average adaptability to all environmental conditions (Table 3 and Figure 1). In the AMMI-1 biplot, $y$ axis represents the effects of interaction (Figure 1). 
Table 2. AMMI variance analysis for fresh forage yield ( $\left.\mathrm{t} \mathrm{ha}^{-1}\right)$ of 20 common vetch genotypes tested in 5 environments

\begin{tabular}{|c|c|c|c|c|c|c|}
\hline $\begin{array}{c}\text { Resource of } \\
\text { variance }\end{array}$ & $\begin{array}{c}\text { Degree of } \\
\text { freedom (DF) }\end{array}$ & $\begin{array}{c}\text { Sum of } \\
\text { squares } \\
\text { (SS) }\end{array}$ & $\begin{array}{c}\text { Mean } \\
\text { squares } \\
\text { (MS) }\end{array}$ & F Value & $\begin{array}{c}\text { G+E+GE SS } \\
\text { Explained (\%) }\end{array}$ & $\begin{array}{c}\text { GE SS } \\
\text { Explained } \\
(\%)\end{array}$ \\
\hline Genotypes & 19 & 2073 & 109.1 & $10.08^{* *}$ & 21.64 & \\
\hline Environments & 4 & 4046 & 1011.6 & $34.62^{* *}$ & 42.23 & \\
\hline Block & 10 & 292 & 29.2 & $2.7^{* *}$ & & \\
\hline GEI & 76 & 3462 & 45.6 & $4.21^{* *}$ & 36.13 & \\
\hline IPCA1 & 22 & 1911 & 86.9 & $8.03^{* *}$ & & 51.18 \\
\hline IPCA2 & 20 & 871 & 43.5 & $4.02^{* *}$ & & 25.62 \\
\hline IPCA3 & 18 & 448 & 24.9 & $2.3 * *$ & & 14.66 \\
\hline IPCA4 & 16 & 232 & 14.5 & $1.34^{\text {ns }}$ & & 8.54 \\
\hline Residuals & 0 & 0 & 0.0 & 0.00 & & \\
\hline Error & 190 & 2057 & 10.8 & & & \\
\hline Total & 299 & 11930 & 39.9 & & & \\
\hline
\end{tabular}

Table 3. Fresh forage yields $\left(\mathrm{t} \mathrm{ha}^{-1}\right)$ means of 20 common vetch genotypes across five environments and IPCAg[1] scores of AMMI analysis

\begin{tabular}{|c|c|c|c|}
\hline \multicolumn{2}{|c|}{ Genotypes } & Grand means (t ha $\left.{ }^{-\mathbf{1}}\right)$ & IPCAg[1] \\
\hline G1 & IFVS 3091 & 20.36 & $-1,481$ \\
\hline G2 & IFVS 2427 & 21.25 & 1,668 \\
\hline G3 & IFVS 715 & 21.24 & $-0,125$ \\
\hline G4 & IFVS 2541 & 22.56 & $-0,227$ \\
\hline G5 & IFVS 3889 & 20.94 & $-0,414$ \\
\hline G6 & D-135 & 26.13 & 0,082 \\
\hline G7 & Kubilay-82 & 16.60 & 0,377 \\
\hline G8 & Dicle & 19.38 & 0,119 \\
\hline G9 & Alinoglu 2001 & 21.13 & $-1,037$ \\
\hline G10 & Kralk1z1 & 19.46 & 0,486 \\
\hline G11 & Gorkem & 19.41 & $-0,742$ \\
\hline G12 & D-71 & 15.85 & 1,403 \\
\hline G13 & Line-22 & 23.71 & $-0,667$ \\
\hline G14 & D-72 & 20.58 & 0,115 \\
\hline G15 & Uludag & 20.20 & $-0,624$ \\
\hline G16 & Ozveren & 19.31 & 0,415 \\
\hline G17 & GAP 2604 & 25.89 & 0,648 \\
\hline G18 & GAP 2490 & 23.62 & $-0,983$ \\
\hline G19 & GAP- 61721 & 18.31 & 0,258 \\
\hline G20 & GAP 59998 & 24.50 & 0,732 \\
\hline
\end{tabular}


Genotypes with IPCA-1 scores close to zero have small interactions and hence show wider adaptation to the tested environments. Namely, genotypes having small IPCA1 values are more stable. (Carbonell et al., 2004; Mirosavljević et al., 2014). In the study, IPCA-1 scores of G3, G4, G6, G8, G14 were to be the closest to zero line, they located close to zero line on the y axis in the AMMI-1 biplot graph. Therefore, these genotypes were considered to conserve fresh forage yield trait in differing environments, with high stability. Despite their lower IPCA-1 scores, close to zero, G8 and G14 can not be recommended due to their lower forage yields, under the grand mean. However, with their high yield means, and lower IPCA-1 scores, close to zero, respectively, G6, G4 and G3 were considered to be possessing high stable forage yields. Therefore, these genotypes should be preferred for forage yield production in Southeastern Anatolia region conditions. A large genotypic IPCA-1 score (either positive or negative) have high interaction and reflects more specific adaptation to the environments with IPCA-1 values of the same sign (Bose et al., 2014). In the study, the highest IPCA-1 scores were recorded in the G1 (-1.481) and G2 (1.668) by far (Table 3 and Figure 1). Hence, these two genotypes were found to be the most unstable genotypes for forage yield trait according to AMMI-1 biplot.

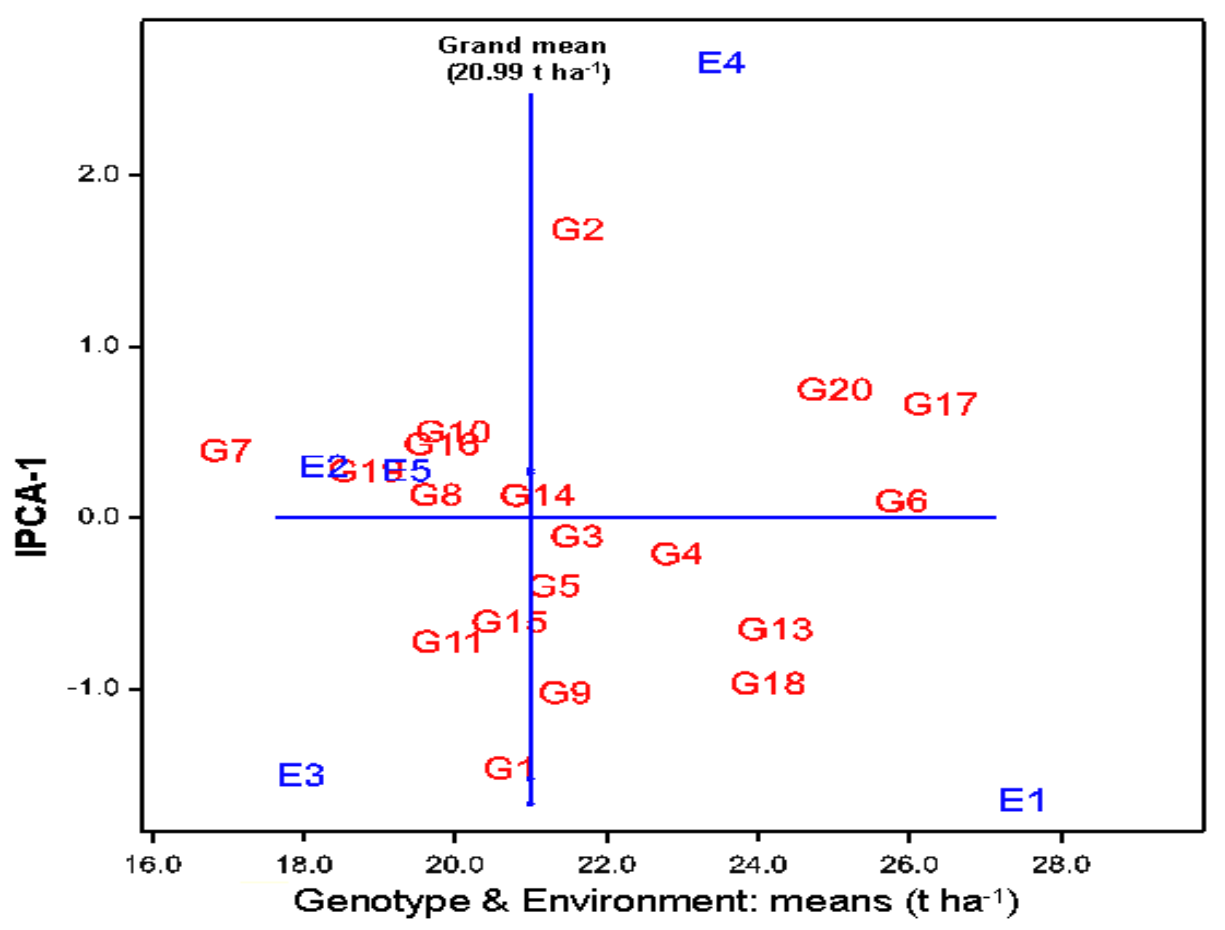

Figure 1. AMMI-1 biplot display fresh forage yields and IPCA-1 scores of 20 common vetch genotypes across five environments

AMMI-2 biplot analysis display both similarity among environments and 
relations between genotypes and environments. Accordingly; E1 and E5 were the most resemble environments for forage yield, because the narrowest angle was found between two the vectors of the environments. Conversely, the most differences showing environments from the other environments were respectively $\mathrm{E} 2$ and $\mathrm{E} 4$, due to the fact that angels of two vectors were the largest ones among the environments (Figure 2). Also, the data shown in the Table 4 confirm this statement.

Table 4. Fresh forage yield means $\left(\mathrm{t} \mathrm{ha}^{-1}\right)$ and IPCA scores of the tested five environments, recommended the first four common vetch genotypes

for each environment

\begin{tabular}{|c|c|c|c|c|c|c|c|}
\hline Number & Environment & Means & IPCAe[1] & $\mathbf{1}$ & $\mathbf{2}$ & $\mathbf{3}$ & $\mathbf{4}$ \\
\hline 1 & E1 & 27.17 & 0.446 & G4 & G9 & G18 & G1 \\
\hline 2 & E2 & 17.93 & -4.365 & G17 & G18 & G20 & G6 \\
\hline 3 & E3 & 17.63 & 1.700 & G3 & G6 & G13 & G9 \\
\hline 4 & E4 & 23.18 & 1.674 & G2 & G3 & G4 & G20 \\
\hline 5 & E5 & 19,03 & 0.546 & G14 & G17 & G13 & G6 \\
\hline
\end{tabular}

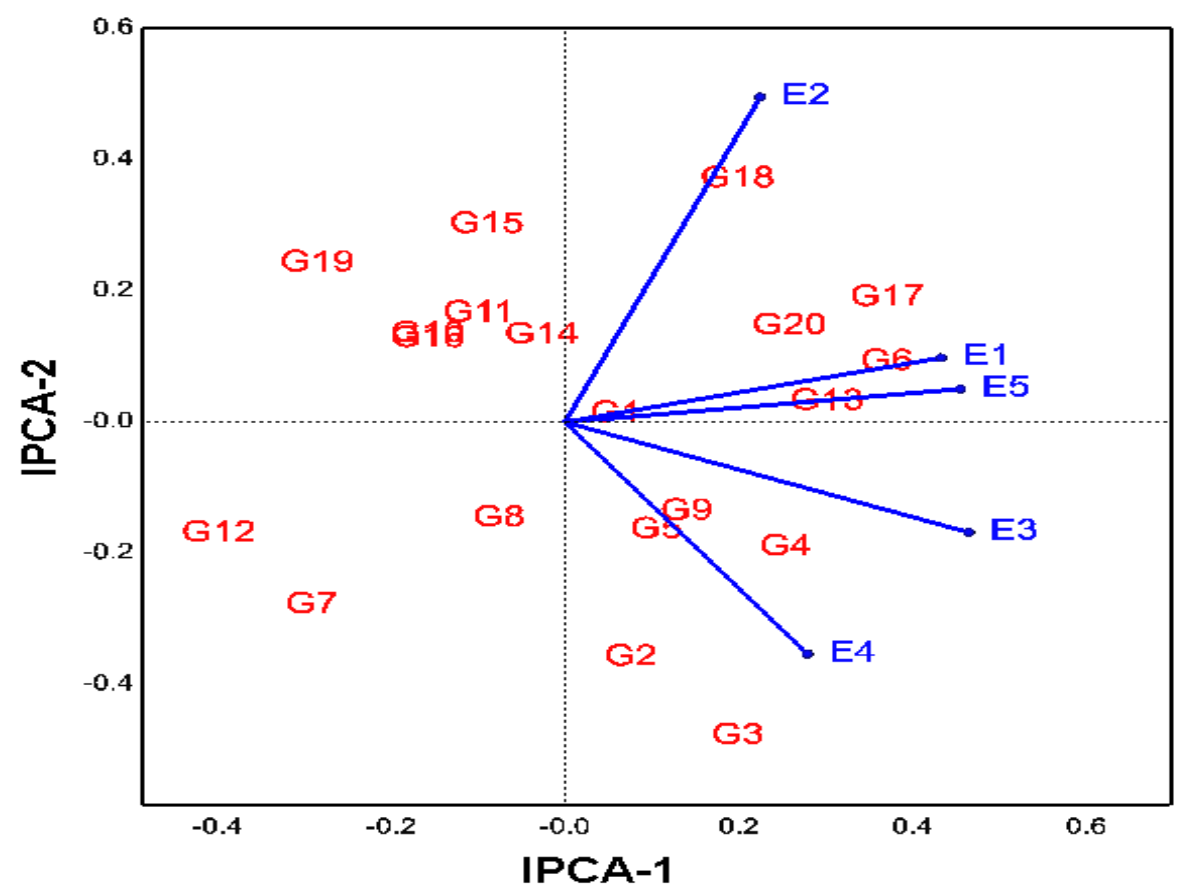

Figure 2. AMMI-2 biplot display response of 20 common vetch genotypes across five environments for fresh forage yield trait.

When genotype $\times$ environment interactions were evaluated from Figure 2 and Table 4, recommended common vetch genotypes for environments showed differences among the environments. Accordingly, respectively, G4, G9, G18, and G1 were recommended for E1 conditions, while G17, G18, G20 and G6 were 
recommended for environmental conditions of E2. Additionally, although G3, G6, G13, G6 genotypes were advised for E3 conditions; G2, G3, G4 and G20 were found to be suitable for forage production in E4 conditions. Also, G14, G17, G13 and G6 respectively were suggested for E5 conditions.

\section{CONCLUSIONS}

Substantial variation was observed in the forage yield mean performance of all the tested genotypes $(\mathrm{G})$ over environments (E) and on the genotype $\times$ environment interactions (GEI). The results indicated that the most effective factor on forage yield performance of common vetch genotypes was the environmental effect $(42.23 \%)$. It was followed by genotype $\times$ environment interactions effect $(36.13 \%)$ and genotype $(21.64 \%)$ effect. AMMI analysis revealed that among the environments $\mathrm{E} 1$ and $\mathrm{E} 4$ were found as favorable environments, and D-135 (G6), IFVS-2541 (G4) and IFVS-715 (G3) respectively had the best stability in terms of fresh forage yield trait in Southeastern Anatolia region conditions.

\section{REFERENCES}

Acikgoz E. (2001). Forage Crops (3rd Press). Uludag University, Faculty of Agriculture, Lecture Book, Publication Number, 182:94-95, Bursa.

Asfaw A, Alemayehu F, Gurum F, Atnaf M, (2009). AMMI and SREG GGE biplot analysis for matching varieties onto soybean production environments in Ethiopia. Scientific Research and Essay, vol. 4 (11) pp. 1322-1330.

Ayed M.H., Gonzalez J., Caballero R., Alvir M.R. (2001). Effect of maturity on nutritive value of field-cured hays from common and hairy vetch. Animal Research, vol. 50, pp. 31-41.

Bose L.K., Jambhulkar N.N., Singh O.N (2014). Additive main effects and multiplicative interaction (AMMI)analysis of grain yield stability in early duration rice. The Journal of Animal \& Plant Sciences, vol. 24(6), pp.1885-1897.

Caballero R., Alzueta C., Ortiz L.T., Rodriguez M.L., Barro C., Rebole A. (2001). Carbonhydrate and protein fractions of fresh and dried common vetch at three maturity stages. Agronomy Journal, vol. 93, pp.1006-1013.

Cakmakci S., Aydinoglu B., Karaca M. (2003). Determining relationships among yield and yield components using correlation and path coefficient analyses in summer sown common vetch (Vicia sativa L.) genotypes. Pak. J. Bot., vol. 35, pp. 387-400.

Carbonell S.A., Filho J.A., Dias L.A., Garcia, A.A., Morais L.K. (2004). Common bean cultivars and lines interactions with environments. Scientific Agriculture, vol. 61(2), pp. 169-177.

Ebdon J.S., Gauch H.G. (2002). additive main effect and multiplicative interaction analysis of national turfgrass performance trials. II cultivar recommendations. Crop Science, vol. 42, pp. 497-506.

Ilker E., Geren H., Unsal R., Sevim I., Tonk F., Tosun M. (2011). AMMI-Biplot Analyses of yield performances of bread Wheat cultivars grown at different locations. Turkish Journal of Field Crops, vol. 16(1), pp. 64-68.

Gabriel K.R. (1971). The biplot graphic display of matrices with application to principal component analysis. Biometrika, vol. 58, pp. 453-467. 
Gauch H.G, Zobel R.W. (1996). AMMI analysis of yield trials. In Genotype-byenvironment Interaction (Kang, M.S. and H.G. Gauch, eds.), CRC Press, Boca Raton, FL: 85-122.

Georgieva N.A., Kosev V.I. (2016). Comparative productivity and adaptive ability of forage pea (Pisum sativum L.) and Vetch (Vicia sativa L.) Cultivars. Journal of Agricultural Science, vol. 8, Issue 6, pp.109-119.

Islam MR, Anisuzzaman M, Khatun H, Sharma N, Islam Z, Akter A, and Biswas PS, (2014) .AMMI Analysis of yield performance and stability of rice genotypes across different Haor areas. Eco. Friendly Agril. J. 7 2:20-24.

Kaya Y, Palta Ç, Taner S, (2002). Additive main effects and multiplicative interactions analysis of yield performances in bread wheat genotypes across environments. Turkish Journal of Agricultural Forestry, 26, 275-279.

Kendal E and Dogan Y. (2015). Stability of a candidate and cultivars (Hordeum vulgare L.) by GGE biplot analysis of multi-environment yield trial in spring barley. Agriculture and Forestry, vol. 61, Issue 4, pp. 307-318.

Kendal, E. (2016). GGE Biplot Analysis of multi-environment yield trials in barley (Hordeum vulgare L.) cultivars. Journal of Crop Breeding and Genetics. vol. 2, Issue 1, pp. 90-99.

Kilic H, (2014). Additive main effect and multiplicative interactions (AMMI) Analysis of grain yield in barley genotypes across environments. Tarım Bilimleri DergisiJournal of Agricultural Science, vol. 20, pp. 337-344.

Mirosavliević M.N., Pržulj N, Čanak P. (2014). Analysis of new experimental barley genotype performance for grain yield using AMMI Biplot. Selekcija Semenarstvo, vol: broj 1.pp: 27-36.

Sayar M.S., Anlarsal, A.E. and Basbag, M. (2010). Current situation, problems and solutions for cultivation of forage crops in the Southeastern Anatolian Region. J. Agric. Fac. HR. U., vol. 14, Issue, 2, pp. 59-67.

Sayar M.S., Anlarsal A.E. and Basbag M. (2013). Genotype-environment interactions and stability analysis for dry-matter yield and seed yield in Hungarian vetch (Vicia pannonica CRANTZ.). Turk. J. Field Crops, vol. 18, Issue 2, pp. 238-246.

Tarakanovas P., Ruzgas V. (2006). Additive main effect and multiplicative interaction analysis of grain yield of wheat varieties in Lithuania. Agronomy Research, vol. 4(1), pp. 91-98.

VSN International, (2011). GenStat for Windows 14th Edition. VSN International, Hemel Hempstead, UK. Web page: GenStat.co.uk

Zobel R.W., Wright M.J., Gauch H.G., (1988). Statistical analysis of yield trial. Agronomy Journal, vol. 80, pp. 388-393. 